Науковий вісник НлТУ України Scientific Bulletin of UNFU

https://nv.nltu.edu.ua

https://doi.org/10.15421/40281007

Article received $28.10 .2018 \mathrm{p}$.

Article accepted 29.11.2018 p.

удк 581.52:582.572.225:502.7 $\begin{array}{ll}\text { (CC) } & \text { ISSN } 1994-7836 \text { (print) } \\ \text { BY ISSN 2519-2477 (online) }\end{array}$

$@ \bowtie$ Correspondence author

I. P. Lyubynets'

rinaemerald2017@gmail.com

І. П. Любинець 1 , І. Г. Хомин ${ }^{2}$

${ }^{1}$ Яворівський національний природний парк, смт Івано-Франкове, Украйна ${ }^{2}$ Природний заповідник "Розточчя", смт Івано-Франкове, Україна

\title{
СТАН ЦЕНОПОПУЛЯЦÏ̈ ALLIUM VICTORIALIS L. НА ТЕРИТОРІЇ УКРАЇНСЬКОГО РОЗТОЧЧЯ
}

Викладено результати дослідження екологічних особливостей Allium victorialis на території Українського Розточчя, подано флористичний склад локалітетів з участю цього виду, описано основні фенологічні фази розвитку цибулі переможної в місцях поширення. На підставі чотирьохрічних спостережень встановлено флуктаційний тип динаміки щільності ценопопуляції, сталість характеру вікового спектра з максимумом на групі особин віргінільного стану, значну кількість ювенільних особин, що може свідчити про добре насіннєве поновлення та сприятливі умови для проростання насіння. За співвідношенням онтогенетичних індексів (віковості та ефективності) віднесено ценопопуляцію до молодого типу. Відзначено присутність особини трьох основних класів віталітету, що зменшує уразливість до несприятливих чинників, ценопопуляція характеризується рівноважним типом віталітетної структури. На підставі показників насіннєвої продуктивності встановлено високу інтенсивність утворення плодів, проте низька частка занасінення і невисокі значення коефіцієнта продуктивності. З'ясовано, що врожай насіння більше залежить від щільності генеративних особин, ніж від значень фактичної насіннєвої продуктивності. Запропоновано список роду Allium для Українського Розточчя доповнити видом Allium victorialis та внести його до нового Переліку видів судинних рослин, що потребують охорони в межах Львівської області.

Ключові слова: щільність; вікова та віталітетна структури; насіннєва продуктивність.

Вступ. Allium victorialis L. (цибуля переможна) гірсько-субальпійська багаторічна трав'яниста кореневищно-цибулева рослина, яка належить до європейсько-малоазіатської групи євроазіатського типу ареалу, який поширений у верхньому лісовому, альпійському та субальпійському поясах у горах Європи (Піренеї, Альпи, Балкани, Карпати) та Малої Азії. Окрім цього ізольовані популяції ростуть в листяних (Розточчя) i темнохвойних лісах, на лісових галявинах, луках Волжсько-Камського регіону, в горах Кавказу, Закавказзя, Сибіру, Алтаю, Далекого Сходу, Сахаліну, Камчатки, Монголії, Японії, Гімалаїв, Північної Америки (Klokov, 1950; Chopyk, 1977; Malynovskii, 1980; Kawano et al., 2005; Pandey et al., 2008; Pistrick et al., 2008.).

Вид запропоновано до Червоної книги Українських Карпат. Знаходиться під охороною у Румунії, Канаді, деяких заповідниках, природних парках Російської Федерації (Seriogin, 2007).

Рід Allium в Україні представлено 42 видами. Згідно 3 аналізом гербарних фондів (збори датовано періодом 1859-2009 рр.) провідних навчальних та наукових закладів м. Львова щодо поширення Allium victorialis, цей вид широко представлений в чотирьох областях Карпатського регіону. Він росте на субальпійських луках, скелях, у верхній частині лісового поясу і в поясі криволісся на висотах від 750 до 1750 м н. р. м. Стосовно Львівської обл. всі 7 гербарних зразків цибулі перемож- ної зібрано в Сколівському районі, де цей рідкісний вид охороняють на території НПП "Сколівські Бескиди". Там він трапляється на полонинах парку, на хребті поблизу г. Парашка та утворює лінійну популяцію із кількох нечисельних локусів по 2-6 генеративних особин (Lyax et Milkina, 2008; Milkina et al., 2011).

Для Українського Розточчя у працях М. Сороки (Soroka, 2000, 2008) наведено 6 представників роду Allium (Allium victorialis у цьому списку не фігурує). Проте В. Ткачик для заповідного урочища "Немирів" описав 2 локалітети Allium victorialis, які, поза сумнівом, знаходяться в рефугіумі плейстоценового періоду, про що свідчить зростання тут окремих видів, які генезисом $\mathrm{i}$ характером сучасного поширення пов'язані з гірськими територіями: Abies alba Mill., Hedera helix L., Aposeris foetida (L.) Less., Dactylis polygama Horvat, Polygonatum vertcillatum (L.) All. тощо (Tkachyk, 1995).

На території Польського Розточчя, а саме в Розточанському парку народовому, цибулю переможну відомо 332 місць росту (Izdebski et al., 1991).

Матеріали та методика дослідження. У 2014 р. на території Українського Розточчя у Немирівському лісництві Рава-Руського ДЛГО у заповідному урочищі "Немирів", яке створене задля збереження залишків ялицевих лісів регіону, виявлено чисельну за кількістю особин популяцію цибулі переможної. Впродовж 20142015 рр. виявлено 9 окремих локалітетів виду, різних за

\section{Інформація про авторів:}

Любинець Ірина Павлівна, начальник науково-дослідного відділу. Email: irynalub@gmail.com

Хомин Іrop Гнатович, наук. співробітник. Email: igor.homyn@ukr.net

Цитування за ДСтУ: Любинець І. П., Хомин І. Г. Стан ценопопуляції Allium Victorialis L. на території Українського Розточчя. Науковий вісник НлТУ України. 2018, т. 28, № 10. С. 36-40.

Citation APA: Lyubynets', I. P., \& Khomyn, I. G. (2018). The state of cenopopulation Allium Victorialis L. on the territory of Ukrainian Roztochchia. Scientific Bulletin of UNFU, 28(10), 36-40. https://doi.org/10.15421/40281007 
площею (від $1 \mathrm{~m}^{2}$ до $800 \mathrm{~m}^{2}$ ), розміщених один від одного на відстанях від декількох десятків до сотень метрів. Популяція розташована на рівнинній місцевості зі слабохвилястим рельєфом, розвиненою яружною системою у правобережній частині басейну р. Блех. Грунти дерново-слабопідзолисті, супіскові.

Важливо зазначити, що заповідне урочище "Немирів" у 2009 р. увійшло до заповідної зони Біосферного резервату "Розточчя" і це зобов'язує приділяти посилену увагу вивченню рідкісних видів фітобіоти.

У 2015 р. на другій терасі р. Блех вибрано локалітет Allium victorialis 3 найбільшою площею поширення, у якому закладено пробну ділянку площею $10 \mathrm{~m}^{2}$ з метою вивчення екологічних умов зростання та особливостей ценопопуляції. Впродовж 2015-2018 рр. на визначеній пробній площі вивчали щільність, вікову, віталітетну структури та насіннєву продуктивність ценопопуляції Allium victorialis за загальноприйнятими методиками (Rabotnov, 1950; Uranov, 1975; Zhykova, 1987, Zhivotovsky, 2001; Zlobin, 1989; Vaynagy, 1974). Математичну обробку результатів проводили згідно з Г. Зайцевим (Zaicev, 1991).

Табл. 1. Флористичний склад ценопопуляцій за участю Allium victorialis L. (весняний аспект) на території Украӥнського Розточчя

\begin{tabular}{|c|c|c|c|c|c|c|c|c|c|c|}
\hline № $3 / \Pi$ & Назва виду & \multicolumn{9}{|c|}{ № локалітету } \\
\hline \multicolumn{11}{|c|}{ Деревний ярус } \\
\hline & Повнота деревостану & 0,4 & 0,4 & 0,5 & 0,4 & 0,7 & 0,6 & 0,6 & 0,6 & $\overline{0,6}$ \\
\hline 1 & Pinus sylvestris L. & + & + & + & + & + & + & + & + & + \\
\hline 2 & Fagus sylvatica L. & + & & + & + & & & & & \\
\hline 3 & Quercus robur L. & + & + & + & + & + & + & + & + & + \\
\hline 4 & Betula pendula Roth & & & & & + & + & + & & \\
\hline 5 & Alnus glutinosa (L.) Gaertn. & + & & & & & & + & & \\
\hline 6 & Carpinus betulus L. & & & & & & + & & & \\
\hline \multicolumn{11}{|c|}{ Підріст } \\
\hline 1 & Abies alba Mill. & + & + & + & + & & + & & & \\
\hline 2 & Picea abies (L.) Karst. & + & + & + & + & + & + & + & + & + \\
\hline 3 & Fagus sylvatica L. & & + & + & & + & & & & \\
\hline 4 & Carpinus betulus L. & + & + & + & + & + & + & + & & \\
\hline 5 & Tilia cordata Mill. & + & + & & & & & & & \\
\hline 6 & Acer platanoides L. & & & & & & & & & \\
\hline 7 & Acer pseudoplatanus L. & & & & & & & & + & \\
\hline \multicolumn{11}{|c|}{ Підлісок } \\
\hline 1 & Corylus avellana L. & + & + & & & + & + & + & & + \\
\hline 2 & Sorbus aucuparia L. & + & & & & & + & & + & \\
\hline 3 & Padus avium Mill. & & & & & & & & & + \\
\hline 4 & Frangula alnus Mill. & & & & & & + & & + & \\
\hline \multicolumn{11}{|c|}{ Трав'янистий ярус } \\
\hline & Загальне проективне покриття & 25 & 30 & 85 & 35 & 35 & 10 & 70 & 90 & 70 \\
\hline 1 & Equisetum sylvaticum L. & & & & & & + & & & \\
\hline 2 & Athyrium filix-femina (L.) Roth & & & & & & + & & 1 & 1 \\
\hline 3 & Dryopteris carthusiana (Vill.) H. P. Fuchs & & & & & & 1 & & & \\
\hline 4 & Stellaria holostea L. & & & 1 & & & 4 & & & \\
\hline 5 & Anemone nemorosa $\mathrm{L}$. & & 5 & 80 & 35 & 30 & & 5 & & + \\
\hline 6 & Rubus hirtus Waldst. et Kit. & & & + & & 2 & 2 & & & \\
\hline 7 & Oxalis acetosella L. & & & & & & 1 & & + & \\
\hline 8 & Hedera helix L. & & & + & 1 & & 1 & & + & \\
\hline 9 & Aegopodium podagraria L. & & & & & & & & + & \\
\hline 10 & Cruciata glabra (L.) Ehrend. & & & & & & & & & + \\
\hline 11 & Pulmonaria obscura Dumort. & & & & & & 1 & & & \\
\hline 12 & Ajuga reptans $\mathrm{L}$. & & & & & & & & & + \\
\hline 13 & Galeobdolon luteum Huds. & & & + & & & 1 & & 2 & 2 \\
\hline 14 & Vaccinium myrtillus L. & & & & & & + & & & \\
\hline 15 & Majanthemum bifolium (L.) F. W. Schmidt & + & + & 4 & 5 & & 1 & & 3 & 2 \\
\hline 16 & Polygonatum multiflorum (L.) All. & & & & & & + & & 2 & 1 \\
\hline 17 & Polygonatum verticillatum (L.) All. & & & & & & + & & & \\
\hline 18 & Allium victorialis L. & 25 & 30 & 30 & 10 & 20 & + & 65 & 80 & 60 \\
\hline 19 & Luzula pilosa (L.) Willd. & & & & & & 1 & & & \\
\hline 20 & Carex sp. & & + & & & & & & & \\
\hline 21 & Carex brizoides L. & & & & & & 2 & & + & \\
\hline & Bryophyta & & 2 & & 2 & & + & & + & \\
\hline
\end{tabular}


ЗПП пізньоосіннього аспекту - $5 \%$ : Allium victorialis - $1 \%$, Stellaria holostea - 1\%, Majanthemum bifolium - $1 \%$, Hedera helix - 1\%, Carex brizoides - 1\%, Oxalis acetosella + , Pulmonaria obscura + , Equisetum sylvaticum + , Athyrium filix-femina -1 , Polygonatum verticillatum +. Окрім цього, описано флористичний склад інших локалітетів цибулі переможної (табл. 1).

Локалітет № 1. Площа $6 \times 3$ м $\left(18,0 \mathrm{~m}^{2}\right)$. Розташування: плато в західному напрямку від мокрого яру.

Локалітет № 2. Площа 7×7 м (49,0 м²). Розташування: південно-західний схил мокрого яру та верх плато. Повнота деревостану 0,4 .

Локалітет № 3. Площа $6 \times 4$ м (24,0 м²). Розташування: західна експозиція берегу яру. Повнота деревостану 0,5 . Вік деревостану близько 60 років.

Локалітет № 4. Площа 1,5×4 м (6,0 м²). Розташування: західна експозиція яру з наявним у ньому невеликим потічком.

Локалітет № 5. Площа $20 \times 40$ м $\left(800,0\right.$ м $\left.^{2}\right)$. Розташування: підвищене плато на другій береговій терасі в долині р. Блех.

Локалітет № 6. Площа $0,20 \times 0,40$ м $\left(0,80 \mathrm{~m}^{2}\right)$. Розташування: рівнинна ділянка в глибині лісового масиву.

Локалітет № 7. Площа $0,20 \times 0,30$ м $\left(0,60 \mathrm{~m}^{2}\right)$. Розташування: рівнинна ділянка в глибині лісового масиву.

Локалітет № 8. Площа 10,0×5,0 м (50,0 м²). Розташування: західний схил мокрого яру.

Локалітет № 9. Площа 10,0×5,0 м (50,0 м²). Розташування: західний схил мокрого яру.

Результати дослідження та їх обговорення. У заповідному урочищі "Немирів" загальна площа поширення цибулі переможної становить близько $1000 \mathrm{~m}^{2}$.

Загалом ці території не вирізняються багатим флористичним видовим різноманіттям (див. табл. 1): тут

Табл. 2. Вікова структура ценопуляції Allium victorialis L. на території Українського Розточчя впродовж 2015 -2018 рр.

\begin{tabular}{|c|c|c|c|c|c|c|c|c|c|c|c|c|}
\hline \multirow{3}{*}{ Рік } & \multicolumn{8}{|c|}{ Віковий стан } & \multirow{3}{*}{$\begin{array}{l}\text { Щільність, } \\
\text { ос./M }\end{array}$} & \multirow{3}{*}{$\begin{array}{c}\text { Індекс відновлення } \\
\text { (Ів), \% }\end{array}$} & \multirow{3}{*}{$\begin{array}{c}\text { Індекс } \\
\text { віковості, } \Delta\end{array}$} & \multirow{3}{*}{$\begin{array}{c}\text { Індекс } \\
\text { ефективності, } \omega\end{array}$} \\
\hline & \multicolumn{2}{|c|}{$\bar{j}$} & \multicolumn{2}{|c|}{ Im } & \multicolumn{2}{|c|}{$\mathrm{v}$} & \multicolumn{2}{|c|}{$\mathrm{g}$} & & & & \\
\hline & $\%$ & oc. & $\%$ & oc. & $\%$ & oc. & $\%$ & oc. & & & & \\
\hline 2015 & 20,8 & 100 & 16,7 & 80 & 50,8 & 244 & 11,7 & 56 & 48,0 & 757,1 & 0,1037 & 0,4827 \\
\hline 2016 & 20,4 & 123 & 22,5 & 136 & 54 & 326 & 3,1 & 19 & 60,4 & 3078,9 & 0,0872 & 0,4361 \\
\hline 2017 & 18,8 & 123 & 26,6 & 174 & 49,8 & 325 & 4,7 & 31 & 65,3 & 2006,5 & 0,0882 & 0,4277 \\
\hline 2018 & 12,5 & 81 & 29,3 & 190 & 45,7 & 296 & 12,5 & 81 & 64,8 & 700 & 0,1043 & 0,4315 \\
\hline
\end{tabular}

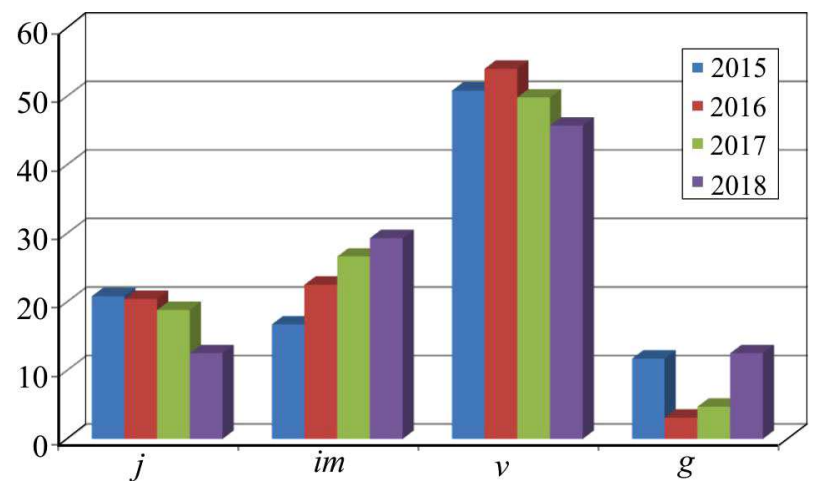

Рис. 1. Вікова структура Allium victorialis L. на території Українського Розточчя впродовж 2015-2018 pp.

Впродовж 2015-2018 рр. характер вікового спектра залишається з максимумом на групі особин віргінільного стану (див. рис. 1). Лише дещо змінюється співвідношення онтогенетичних груп: роль ювенільних особин у віковому спектрі знижується у 1,7 раза, іматурних зростає в 1,8 раза, частка віргінільних особин найвища в 2016 р., а генеративних - найбільш варіабельна - спо- присутні 11 видів деревних видів, 4- чагарникових, 21 - трав'янистих. Окрім цього, на території лісового кварталу, але поза межами локалітетів, виявлено види рослин, занесені до Червоної книги України, а саме: Huperzia selago (L.) Bernh. ex Schrank et Mert., Lathyrus laevigatus (Waldst. et Kit.) Gren., Galanthus nivalis L.

Варто зазначити, що виявлені ділянки цибулі переможної характеризуються різновіковою структурою, наявністю як значної кількості генеративних особин, так і молодих рослин, що засвідчує не лише про добре вегетативне поновлення виду, а й про достатнє насіннєве.

Впродовж вегетаційного періоду спостерігали за основними фенологічними фазами розвитку цибулі переможної в цьому регіоні: початок вегетації - середина березня; повний розвиток вегетативної маси - початок квітня, - масова бутонізація середина травня; до 1 декади червня - масове цвітіння від другої половини травня; утворення плодів, достигання насіння та розкривання коробочок впродовж червня, висипання насіння - кінець червня - друга декада липня; початок пожовтіння листя окремих особин остання декада липня. Окремі пожовклі особини виду ще фіксували в першій декаді жовтня.

За роки вивчення відзначено незначну зміну щільності особини $A$. victorialis (особливо за період 20162018 рр.). Середнє значення щільності становить 59,6 oc./ $\mathrm{M}^{2}$. На закладеній пробній площі вид поширений нерівномірно, абсолютна чисельність особин в окремих квадратах трансекти змінюється від 0 до 161. Відповідно і чисельність особин різних вікових груп на квадратний метр змінюється в межах: ювенільних - 0 30 , іматурних - 0-56, віргінільних - 0-87, генеративних -0-23 (табл. 2, рис. 1). чатку зменшується майже в 4 раза (2016-2017 рр.), потім знову досягає рівня 2015 р. Щільність генеративних особин найбільше впливає на індекси відновлення та віковості, які часто обернено пропорційні (рис. 2).

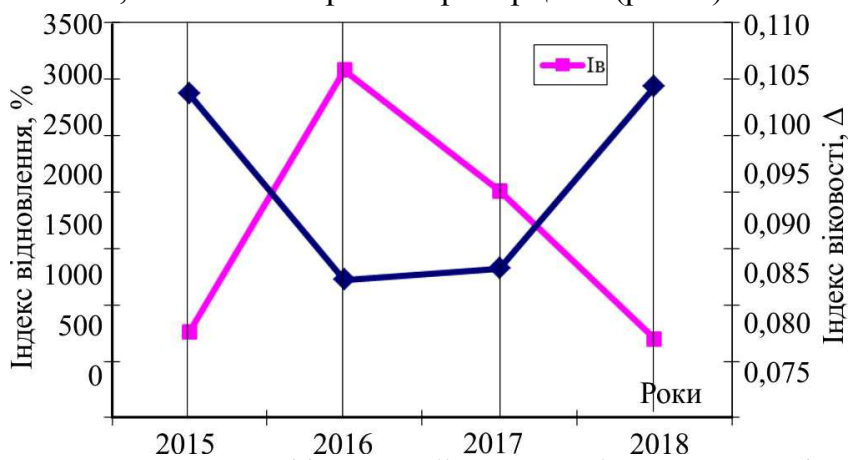

Рис. 2. Онтогенетичні індекси Allium victorialis L. на території Українського Розточчя впродовж 2015-2018 pp.

Оскільки загальна щільність особин за роки вивчення змінюється незначно, невисоке значення щільності квітучих рослин у 2016 р. вплинуло на найвищий показник індексу відновлення та найнижчий - індексу віко- 
вості в цей рік. Значна кількість ювенільних особин може свідчити про добре насіннєве поновлення та сприятливі умови для проростання насіння.

Співвідношення онтогенетичних індексів (віковості та ефективності) (див. рис. 2), за Животовським (Zhivotovsky, 2001), дає змогу віднести вивчену популяцію до молодого типу.

Особини обстеженої популяції A. victorialis характеризуються високою (2016 р.) та середньою життєвістю (2015, 2017-2018 рр.), про що свідчить їхній процвітаючий та рівноважний віталітетний тип у відповідні роки (табл. 3).

Табл. 3. Віталітетна структура ценопуляції Allium victorialis L. на території Українського Розточчя впродовж 2015-2018 рр.

\begin{tabular}{|c|c|c|c|c|c|}
\hline \multicolumn{3}{|c|}{ Клас віталітету } & \multirow{2}{*}{$\begin{array}{l}\text { Індекс } \\
\text { якості }\end{array}$} & \multirow{2}{*}{$\begin{array}{l}\text { Статистична дос- } \\
\text { товірність, \% }\end{array}$} & \multirow{2}{*}{$\begin{array}{c}\text { Віталітетний } \\
\text { тип }\end{array}$} \\
\hline$a$ & 8 & $c$ & & & \\
\hline 0,44 & 0,2 & 0,36 & 0,32 & 97 & рівноважна \\
\hline 0,40 & 0,3 & 0,28 & & 60 & \\
\hline 0,32 & 0,28 & 0,40 & 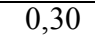 & 96 & $\mathrm{p} 1 \mathrm{~B}$ \\
\hline 0,24 & 0,36 & 0,40 & 0,30 & 96 & рівноважна \\
\hline
\end{tabular}

Оскільки віталітетний склад популяцій є динамічною характеристикою й у випадку зміни еколого-ценотичних чинників, віталітетний спектр також змінюється (Zlobin, 1989), можна припустити, що в останні роки вивчення дещо погіршились через екологічні умови існування (рис. 3). Про це свідчить переважання у віталітетному спектрі 2017-2018 pp. особин низької життєвості (с-класу), які є ознакою адаптивного запасу (потенціалу) популяції, що дає змогу не лише пристосуватися та вижити в несприятливих умовах, але й бути певним резервом для відновлення популяції (Zhyliaev, 1989; 2005).

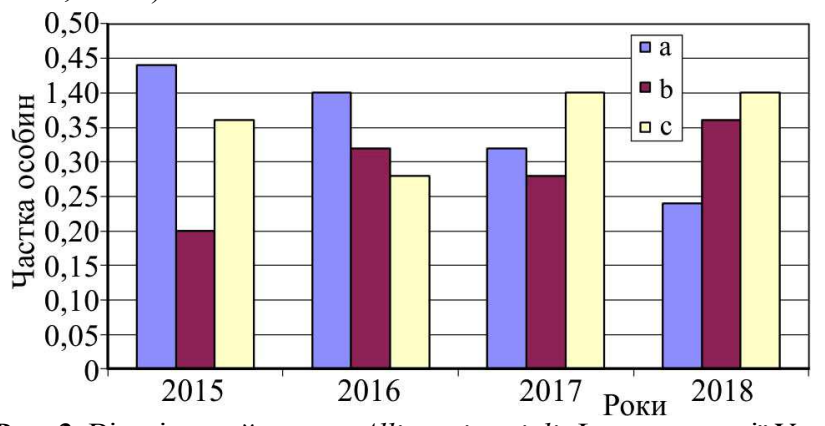

Рис. 3. Віталітетний спектр Allium victorialis L. на території Українського Розточчя впродовж 2015-2018 pp. (a, в, с - класи віталітету)

Оскільки плід цибулі переможної - це коробочка кулясто-тригранна, зі широкозворотними-серцеподібними стулками (Flora, 1935), у кожному гнізді коробочки цибуль може розміщуватися по 2 насінини, тобто потенційно у коробочці може дозрівати 6 насінин. Під час дослідження насіннєвої продуктивності цибулі переможної встановлено, що в досліджуваного виду у природних умовах плід містить лише 1-3 насінини, а саме здебільшого (71,6\%)- одну, значно рідше - дві $(19,5 \%)$ і три $(8,9 \%)$. Тому впродовж років вивчення усереднені показники кількості дозрілих насінин на плід змінюються в межах 1,2-1,48. Як результат, на фоні достатньо високого відсотка плодоцвітіння, фактична насіннєва продуктивність значно менша від потенційної, на що вказують невисокі значення Кпр $(23,4$ $35,1 \%$ ) (табл. 4).
Табл. 4. Насіннєва продуктивність Allium victorialis L. на території Українського Розточчя впродовж 2015-2018 pp.

\begin{tabular}{|c|c|c|c|c|c|c|c|}
\hline \multirow[b]{2}{*}{ 党 } & \multicolumn{3}{|c|}{ Кількість, шт. } & \multirow{2}{*}{ 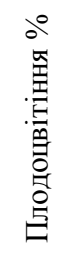 } & \multicolumn{2}{|c|}{$\begin{array}{l}\text { Насіннєва про- } \\
\text { дуктивність }\end{array}$} & \\
\hline & 总皇 & $\begin{array}{l}\text { 臽 } \\
\text { 兒 }\end{array}$ & 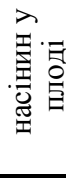 & & 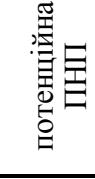 & 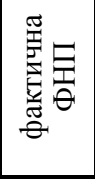 & \\
\hline 2015 & $37,2^{ \pm 1,5}$ & $18,88^{ \pm 1,2}$ & 1,38 & 50,8 & 111,6 & 26,1 & 34 \\
\hline 2016 & $27,0^{ \pm 1,5}$ & $19,2^{ \pm 1,3}$ & 1,48 & 71,3 & 81,0 & 28,4 & \\
\hline 2018 & $32,4^{ \pm 1,5}$ & $24,2^{ \pm 1,5}$ & 1,2 & 74,7 & 97,2 & 29,12 & \\
\hline
\end{tabular}

Хоча фактична насіннєва продуктивність у 2016 р. дещо вища, ніж у 2015 р., значення врожаю насіння у 2016 р. менше. Отже, врожай насіння більше залежить від щільності генеративних особин, ніж від значення фактичної насіннєвої продуктивності (щільність генеративних особин у 2015 р. майже в 3 рази вища від аналогічного значення 2016 р.) (рис. 4).

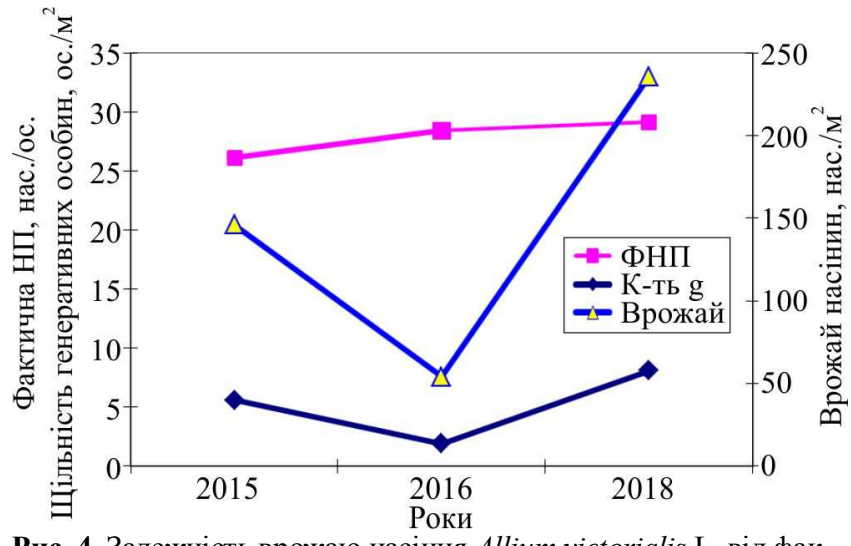

Рис. 4. Залежність врожаю насіння Allium victorialis L. від фактичної насіннєвої продуктивності та щільності генеративних особин

Висновки. Отже, список видів Allium L для теритоpiї Українського Розточчя поповнився A. victorialis L., до відомих A. ursinum L., A. scorodoprasum L., A. montanum F. W. Schmidt, $A$. angulosum L., A. oleraceum L., A. carinatum, L. (Soroka, 2008) і нараховує 7 видів.

Сучасний стан вивченої ценопопуляції $A$. victorialis можна охарактеризувати як задовільний: чисельність підтримується вегетативним та насіннєвим способами, щільність відносно стала, тип популяції - молода, повночленна. Добре насіннєве поновлення за невисокого значення коефіцієнта насіннєвої продуктивності, належність дослідженої ценопопуляції до рівноважного типу віталітетної структури свідчить про екологічний оптимум умов існування для цього виду.

3 огляду на нечисельність популяцій Allium victorialis на території області, унікальність їхньої наявності на рівнині, а саме в межах Українського Розточчя, пропонуємо внести цей рідкісний вид до нового Переліку видів судинних рослин, що потребують охорони в межах Львівської обл. (видів регіональної охорони).

\section{Перелік використаних джерел}

Izdebski, K., Czarnecka, B., Grądziel, T., Lorens, B., \& Popiołek, Z. (1991). Mapy zbiorowisk roślinnych i rozmieszczenia roślin rzadkich Roztoczańskiego Parku Narodowego. Roztoczański Park Narodowy. Lublin, 25 map: kolor.; w tece 32x22 cm. [In Polish].

Komarov, V. L. (Ed.) (1935). Flora SSSR. Leningrad: AN SSSR, 760 p. [In Russian]. 
Liakh, I. V., \& Milkina, L. I. (2008). Natsionalnyj pryrodnyj park "Skolivski Beskydy". Nelisova roslynnist, (pp. 50-51). Lviv: Spolom. [In Ukrainian].

Milkina, L. I., Deineka, A. M., \& Pryndak, V. P. (2011). Natsionalnyj pryrodnyj park "Skolivski Beskydy". Rarytetnyj fitigenofond. Lviv: Kamula, 140 p. [In Ukrainian].

Soroka, M. I. (2008). Roslynnist Ukrainskoho Roztochchia. Lviv: Svit, 434 p. [In Ukrainian].

Tkachyk, V. P. (1995). Znakhidka Allium victorialis L. v Ukrainskii chastyni Roztochchia. Ukrainian Botanical Journal, 32(4), 544 545. [In Ukrainian].

Zhyliaev, H. H. (2005). Zhyznesposobnost populiatsyi rastenyi. Lviv: Publishing house NAN Ukrainu, In-t Ekologii Karpat, 304 p. [In Russian].

Zhyvotinskij, L. A. (2001). Ontogeneticheskie sostoyaniya, effektivnaya plotnost' I klassifikatsiya populyatsij rastenij. Ekologiya, 1, 37. [In Russian].

Zlobin, Ju. A. (1989). Teoriya i praktika otsenki vitalitetnogo sostava rastenij. Botanical journal, 74(6), 769-781. [In Russian].

И. П. Любинец ${ }^{1}$ И. И. Хомин ${ }^{2}$

${ }^{l}$ Яворовский национальный природный парк, пгт Івано-Франково, Украина

${ }^{2}$ Природный заповедник "Расточье", пгт Ивано-Франково, Украина

\section{СОСТОЯНИЕ ЦЕНОПОПУЛЯЦИИ ALLIUM VICTORIALIS L. HA TЕРРИТОРИИ УКРАИНСКОГО РАСТОЧЬЯ}

В статье изложены результаты исследований экологических особенностей Allium victorialis на территории Украинского Расточья. представлено флористическое разнообразие локалтетов при участии данного вида, описаны основные фенологические фазы развития лука победного в местах распространения. На основании четырёхлетних исследований определён флуктационный тип динамики плотности популяции, стабильность характера возрастного спектра с максимумом на группе особей виргинильного состояния, значительное количество ювенильных особей, что может свидетельствовать о хорошем семенном возобновлении и благоприятных условиях для проростания семян. В соответствии с онтогенетическими индексами (возрастности и эффективности) ценопопуляцию можно отнести к молодому типу. Отмечено присутствие особей трёх основных классов виталитета, что уменьшает подверженность к неблагоприятным условиям. На основании показателей семенной продуктивности установлено высокую интенсивность образования плодов, при этом низкий процент осеменения и невысокие значения коэффициента продуктивности. Определено, что урожай семян более зависит от плотности генеративных особей, нежели от значений фактической семенной продуктивности. Предлагается список рода Allium для Украинского Расточья дополнить видом Allium victorialis и внести его к новому Перечню видов сосудистых растений, которые требуют охраны в пределах Львовской области.

Ключевые слова: плотность, возрастная и виталитетная структура, семенная продуктивность.

I. P. Lyubynets'1, I. G. Khomyn ${ }^{2}$

${ }^{I}$ Yavorivskiy National Natural Park, Ivano-Frankove, Ukraine

${ }^{2}$ Roztochia Nature Reserve, Ivano-Frankove, Ukraine

\section{THE STATE OF CENOPOPULATION ALLIUM VICTORIALIS L. ON THE TERRITORY} OF UKRAINIAN ROZTOCHCHIA

The article describes the distribution of the mountain species Allium victorialis on the plain, namely, within the framework of the Ukrainian Roztochya. The authors delineate the floristic composition of the localities with the participation of this species and the main phenological phase of victory onion in the region. According to the generally accepted methods of studying, we determined the features of populations, density, age, vitality structure, and seed productivity of $A$. victorialis coenopopulation. In the course of research, on the basis of four-year observations we have found the dynamic fluctuations of the coenopopulation density and the constant character of the age spectrum with the maximum on the group of individuals of the virgin state, and a significant number of juvenile individuals, which may indicate good seed restoration and favourable conditions for seed germination. The ratio of ontogenetic indices (age and efficiency) is attributed to the coenopopulation to the young type. We noted the presence of the individuals of three main classes of vitality, which reduces the vulnerability to adverse factors. On the basis of seed productivity indicators, a high intensity of fruit formation, but a low percentage of germination and low values of the productivity coefficient were registered. We have also determined that the seed yield depends more on the density of generative individuals than on the actual seed productivity. We have noted that the present state of the studied coenopopulation of $A$. victorialis can be characterized as satisfactory as the number is supported by vegetative and seed reproduction, the density is relatively stable, and the type of population is young. A good renewal of seeds at a low value of the seed productivity coefficient, the belonging of the studied coenopopulation to the equilibrium type of the vital structure shows the ecological optimum of the existence conditions for this species. Therefore, the list of the Allium for Ukrainian Roztochya is proposed to be supplemented with the species Allium victorialis and added to the new list of types of vascular plants which require protection within Lviv Region.

Keywords: density; age and vitality structure; seed production. 